\title{
ON C. S. PEIRCE'S PRIMARY ARITHMETIC
}

\section{SOBRE A ARITMÉTICA ELEMENTAR DE C. S. PEIRCE}

\author{
Antonio Vicente Marafioti Garnica ${ }^{1}$ \\ Leandro Josué de Souza ${ }^{2}$ \\ Maria Ednéia Martins Salandim ${ }^{3}$
}

\begin{abstract}
This paper presents the initial studies on Peirce's Primary Arithmetic, a set of manuscripts, never published by the author, written at the end of the XIX century. The originals - organized and published by Carolyn Eisele in 1976 - was translated to Portuguese and some initial studies are being developed focusing on the possibility that some features of Peirce's Philosophy could be pragmatically but implicitly - present in such manuscripts. Our partial conclusions, now, show that Peirce's life circumstances, more than his Philosophy, characterize the texts under examination.
\end{abstract}

Keywords: Charles S. Peirce; Primary Arithmetic; Mathematics Education; History; Philosophy; Peirce's Mathematical Writings.

Resumo: O artigo apresenta estudos iniciais acerca da Aritmética Elementar de Peirce, uma série de manuscritos elaborados ao final do século XIX, nunca publicados por seu autor. Os originais - organizados e publicados por Carolyn Eisele em 1976 - foram traduzidos para o português e nossa abordagem inicial a esses textos tem como foco compreender se as abordagens filosóficas peirceanas desempenham pragmaticamente, mesmo que implicitamente - algum papel nessa produção voltada para a Escola Primária americana. Nossas conclusões - parciais - mostram que as circunstâncias da vida de Peirce, mais do que sua Filosofia, caracterizam esses Manuscritos.

Palavras-chave: Charles S. Peirce; Aritmética Elementar; Educação Matemática, História; Filosofia.

\section{A Brief Biographical Account}

Our most recent studies on Charles Sanders Peirce led us to look for his texts regarding the teaching of mathematics, therefore we inscribe these works in a domain that intersects mathematics education, history, and philosophy of mathematics education. We specifically tried to study and translate a set of manuscripts that we called Peirce's Primary Arithmetic. This was a body of notes produced at the end of the XIX century, never published or completed by the author, which were made public in the 1970s, when they were recovered by Carolyn Eisele and published as part of the Peircean mathematical

$1 \mathrm{PhD}$ in Mathematics Education, UNESP-Rio Claro. UNESP-Bauru, SP, Brazil. E-mail: vicente.garnica@unesp.br

2 Master in Science Education, UNESP-Bauru, SP, Brazil. E-mail: leandro.josue@unesp.br

$3 \mathrm{PhD}$ in Mathematics Education, UNESP-Rio Claro. UNESP-Bauru, SP, Brazil. E-mail: maria.edneia@unesp.br 
production (NE, 1976) ${ }^{4}$. The objective of this article is to present our initial studies to a foreign audience since, to date, all research regarding this theme has been publish in Portuguese.

Seeking to understand possible approximations between Peirce and the philosophy of education (and, by extension, the philosophy of mathematical education), we believe it is necessary to start with some biographical data.

Charles Sanders Peirce was born on September 10, 1839, in Cambridge, Massachusetts, USA. He was the second of four sons of a cultured, prominent, and affluent family, which meant Charles enjoyed a privileged upbringing and had access to excellent academic opportunities in the United States of his time (NE, 1976).

Charles Peirce experienced almost every form of education. First, his father homeschooled him and then allowed him to attend private schools "whose relative lack of rigorousness must have been a pleasant surprise". With that type education Benjamin Peirce believed to have been able to awaken the genius that Charles supposedly had. However, according to his biographers, this also caused the young man a string of problems, making it hard for him to fit in, thus leading to lifelong relationship difficulties. (O’CONNOR; ROBERTSON, 2005).

Peirce had varied activities, however, according to his biographers, the hand of his father, who seemed to have been his greatest personal and scientific reference throughout his life, can be seen in the opportunities presented to him (EISELE, 1959). He was a lecturer at Harvard, in 1865, and at the Lowell Institute, in January of 1867 (O'COONOR; ROBERTSON, 2005). Benjamin's position as superintendent of United States Coast and Geodetic Survey ${ }^{5}$ opened many doors for Charles to learn about the scientific method. In 1870, Charles Peirce was part of the Coast Survey expedition to the

\footnotetext{
${ }^{4}$ The eight volumes of the Collected Papers of Charles Sanders Peirce, published by Harvard University Press, have been one of the most important sources for references on Peirce. But since 1958 - the year Arthur Burks edited the last volume - some other editions became public, complementing the Collected Papers. Surely it demonstrates the increasing academic interest on Peircean works, but at the same time it represents a problem for making unambiguous reference citations on the original manuscripts. Nowadays we need to recognize the efforts of Indiana University's Peirce Edition Project in publishing the complete writings of Peirce in a chronological edition (7 volumes available, 30 projected) and other initiatives which will naturally appear in this paper. In order to make references clear and facilitate reading, we use a special notation for all Peirce's original quotations, noting down in capital letters the editions used followed by the page numbers. We use CPn to indicate volume $\mathrm{n}$ of Collected Papers, CEn for the volume $\mathrm{n}$ of Chronological Edition, EPn for the volume n of The Essential Peirce, NEn for the volume n of The New Elements of Mathematics, EW for Essential Writings, SE for Selected Writings, PW for Philosophical Writings and so on.

5 Coast and Geodetic Survey was created by an Act of the American Congress in 1807, during the administration of Thomas Jefferson and continues to operate to this day. Its main objective is to produce nautical information, as well as border, commerce e defense issues.
} 
Mediterranean Basin to observe the solar eclipse, while Benjamin was personally managing the program. In 1872, Charles himself was also temporarily at the helm of the Coast Survey Office. Besides that, even though he became an assistant at the Coast Survey, he continued to work at the Harvard Observatory, with outstanding success until 1875 .

With his career in full swing and all the work in science, Peirce kept to his greatest interest: the study of philosophy and logic. In 1879, he started his work as a lecturer in logic in the College of Mathematics at Johns Hopkins University (1879 - 1884), the only teaching position he had throughout his life. Johns Hopkins University was the first graduate school in the United States, where its first president, Daniel C. Gilman, had gathered brilliant minds such as Cayley, Sylvester, Lord Kelvin, and William James, among others.

American mathematics flourished with the arrival of James Joseph Sylvester, whose mathematical vitality and ability to inspire others created a powerful hub of mathematicians ${ }^{6}$ at Johns Hopkins University. As a result, Sylvester launched the American Journal of Mathematics in 1878 (NE, 1976). Peirce had personal difficulties with Sylvester, as well as several other professors and scholars at that institution.

In the five years he worked at Johns Hopkins, Peirce taught several courses, however he did not attract more than a handful of students. The created the Metaphysical $C l u b^{7}$, which was a great success, and took part in several academic bodies within the university, such as the Scientific Association and the Mathematical Seminary, where he was able to present significant work. Charles Peirce took a highly active and influential role in the intellectual issues at Johns Hopkins, but not in political matters, from which untenured members like him were barred. This was a source of great frustration for him. (BRENT, 1998).

For Brent (1998), between 1890 and 1900, Peirce was in full decadence and he even compared his suffering to that of Christ. A lot of Peirce's work from this moment of decadence on was either rejected for publishing or never completed. Examples of the

\footnotetext{
${ }^{6}$ It is important to remember that few American mathematicians had reached such prominence before. The most well-known at the time is Benjamin Peirce, an 1829 Harvard graduate, highly influential both from a scientific and academic policies standpoint.

${ }^{7}$ From 1871 to 1874 Peirce was a member of a club in Harvard, whose members met to discuss several philosophical issues. Pragmatism reportedly arouse from the such discussions. Even though club members did not mention him much, Charles S. Peirce was very enthusiastic about it, to the point of mentioning it frequently (BRENT, 1998).
} 
former are How to Reason (1894) and New Elements of Mathematics (1895). In the latter category are Search for a Method (announced in 1893, but never completed), The Principles of Philosophy (12 volumes announced in 1894, but never completed) and The History of Science (announced in 1898, but never completed) (O'COONOR; ROBERTSON, 2005).

Peirce's last years were spent with his second wife in his property called Arisbe, where a lot of energy and time had to be spent in mundane tasks due to the poverty of that period. Even though Peirce was still interested in science, his scientific production came to a significant halt in the last decade of his life (EISELE, 1959).

Peirce died at 74, on April 19, 1914, after living out his days in extreme poverty.

Much of Peirce's extreme mood swings, detected early on, increased as he grew older. Suffering from dangerous psychological instabilities and depression, he was greatly pampered by his parents, even as an adult, at the age of thirty or forty. Despite such disorders, under the tutelage of his father, Peirce developed a high degree of discipline, meaning that he could work on his problems intensely and in a concentrated manner, for several days and sometimes even months, with the help of drugs.

The list of American and European scholars significantly influenced by Peirce's work included, among others, William James, and John Dewey. Nonetheless, Peirce seems to have gotten little recognition from American scholars of his time. His personality traits were such that he often offended eminent people. Despite Peirce's intellectual value, various achievements and importance, his disagreeable manner, lack of social skills, arrogance, often dubious morals, and his mental instability made life extremely complicated (BRENT, 1998).

\section{Peirce, Philosophy and Education}

A brief bibliographical review ${ }^{8}$ seems sufficient to attest to the potential of Peirce's work for education, particularly, mathematics education. There are similarities between Peircean and other theories that should be studied. There lies the possibility of taking advantage of Peircean pragmatism and his theory of signs as a philosophical foundation for mathematics education. Two of the publications reviewed (STROM et alliin, 1999 and CASSIDY, 1982) attest to how useful Peirce's philosophical work can be as a

\footnotetext{
${ }^{8}$ Although the complete bibliographical review we have done to give foundation to this study is not presented in this paper, all the references are listed below.
} 
methodological parameter. These possibilities, however, should not situate Peirce as a philosopher of education. The few texts he wrote on the subject are based more on his experience as a teacher and student, and on the common sense of the thinker in sync with his time, and with the possibilities of the future, and are not, as might be thought ${ }^{9}$, an attempt to establish a philosophy of education. Peirce's thoughts on education are, at best, fragmentary.

We must recognize the well-known influence Peirce had on Dewey's philosophy ${ }^{10}$, one of the most important and influential American philosophers of education. McCarthy (1971) points out that, despite all this, Peirce was curiously and uncharacteristically silent on educational issues. McCarthy analyzes some documents collected by editors - at a time when most of Peirce's essays had not yet been published - looking for evidence of a possible Peircean educational philosophy. But the author clearly states that, just because a man's thinking had powerful implications for education, it certainly does not mean that he was a philosopher of education.

As his main references, McCarthy uses a letter from Peirce to Daniel Coit Gilman (SW, pp. 325-330), a short paper published in the Educational Review in 1898 (SW, p. 338-341) and his assignment for the Century Dictionary published in 1889, for which he was one of the editors (SW, pp.332-335). McCarthy's paper was published in 1971, six years before Eisele published The New Elements of Mathematics by C. S. Peirce, and although McCarthy considers the contribution Peirce made to the methods of teaching mathematics as "evident from a series of manuscripts he prepared for three mathematics texts which were never published", no more detailed references on this issue are presented. However, in discussing some possible further research on Peirce's mathematical works, he points out:

\footnotetext{
Unfortunately, the reader who is not thoroughly grounded in mathematics is able to derive from these manuscripts only that Peirce had a sound concept of the order in which different types of mathematics ought to be taught, and that his schemes for scrapping rote learning and to involve the learner's imagination seem to anticipate the methods of the 'New Math'.
}

\footnotetext{
9 Approaches and terminology can cause confusion, such as in the case of the so-called Peircean phenomenology, mistakenly interpreted as a proximity of Peirce to Husserl's phenomenology (consult RANSDELL, 1989, for more information on this). Some liberties are also taken on the link between pragmatism and Peirce's sign theory. According to Cooper, (1967), "Peirce's sign theory is not strictly necessary to his pragmatism, which can be taken as a logical role related to the conceptions of inquiry and inference. But much of the richness of Peirce's thought, his creative and largely independent construction of pragmatism as a general philosophic frame, would thereby be lost as would some of the relation to Dewey's later sign theory" (p. 12).

${ }^{10}$ John Dewey foi um dos primeiros estudantes a obter o Ph.D. em Filosofia na Johns Hopkins (SW, 1958).
} 
Nowadays, we can analyze the mathematical writings from a distinct perspective for they are all available in Eisele's edition, and also McCarthy's citation about New Math - which he seems to approve - can be considered in a quite different way (see, for instance, KLEIN, 1970). Peirce's remarks on education in the papers used by McCarthy - currently published under the label "Science and Education" in Wiener's 1958 edition in short, focus on Peirce's points of view which are not founded - or not explicitly founded - in his philosophy. There are no traces of pragmatism, or of the Peircean theory of signs when, in the letter to Gilman, Peirce exposed his thoughts regarding the organization and administration of an academic department. But an educational concern can be detected there:

/.../ the professor's objectives ought to be to let the pupil as much into the interior of the scientific way of thinking as possible, and for that purpose he should make his lecture experiments resemble real ones as much as possible, and he should avoid those exhibitions of natural magic which impress the mind with a totally perverted idea of Science (SW, p. 326).

However, the implementation of an action-guided methodology within the laboratory in an inquiry approach - whose clear intention is to approximate, as closely as possible, the preparation of future physicists' with real practice and conditions, sharing responsibilities - is to be used only with the special students. The methods to be used with "general" students are lessons and lectures. Moreover, this approach has new elements under consideration: beyond this treatment which involves lecturing, pupils ought to be exposed to the moral and logical lessons of physics, instructed as to the purposes, ideas, methods, and life of the physicist. The main laws of physics must be taught to them in all their possible applications.

In regard to the system of instruction, the special pupils would give little trouble. They should be apprentices in establishment, above all. They should be left to work out the mathematics of practical problems in order that their mathematics might not be up in the air; they should also be made to study out new methods and make designs for new instruments, the instructor measuring their strength. /.../ Some of the merits of this method are that from the first the pupil feels himself an apprentice - a learner but yet a real worker; he is introduced to a great and important investigation and of this investigation he has a necessary part to do, he is not working for practice merely. /.../ The method with general students, in my opinion, is a more difficult problem than that with special students. For them are lessons. A lesson should be neither a recitation nor a lecture but something like a mixture of the two (SW, pp 3289) 
Peirce's definition and remarks on the function of a university are also made clear in his entry to the Century Dictionary ${ }^{11}$, which is remarkable in that it makes not the slightest allowance for the function of instruction. McCarthy (1971) tells us that the other editors wrote to him that they conceived the university as an institution for instruction. Peirce replied as follows "If they have any such notion, they were grievously mistaken, that a university had not and never had had anything to do with instruction and that until we got over this idea, we should not have any university in this country" (p. 10).

In his text, however, we find a remark on instruction being only a necessary means to the main purpose and function of a university: the production of knowledge. Also, in this text Peirce deplored the tendency to evaluate professorial contributions in economic terms rather than in terms of theoretical research and affirms that universities seem to proclaim to its students that their individual well-being is its only aim. It would be possible and interesting - although probably monumental and thankless labor - to elaborate in full detail what Peirce might have proposed as a Peircean philosophy of education.

Peirce's mathematical work shows another side of the author that can be studied more deeply by researchers in Mathematics Education. Those manuscripts show inventiveness in the use of nomenclature, creativity in approach, and innovation. In particular, the manuscripts referring to his work in elementary mathematics (arithmetic, studied here) allow an analysis of Peirce's thinking about mathematics education. The emphasis on the link between the structure of language and the teaching of mathematics, the exploration of algorithms, the care taken to establish dialogues between diverse areas of knowledge (an initiative that has been given priority nowadays in proposals for education - interdisciplinarity), among other elements that await more detailed analysis, all these reinforce the potential of investing in Peirce.

Charles S. Peirce is not an easy author. According to some of his critics, he wrote for a variety of readers, from very technical and specialized individuals to the layman, without abandoning his encyclopedic erudition or his ideals of logical rigor and philosophical integrity. He was an original and independent scholar, whose main concern was research, in which he pioneered in exact sciences and philosophy. Moreover, he coined new technical terms and, as a result, used vocabulary that was alien both to

${ }^{11}$ The Century Dictionary and Cyclopedia is one of the largest encyclopedic dictionaries of the English language. 
scientific and colloquial discourse. These characteristics are reflected in his work, rendering it arid and making him a lonely thinker (SW, 1958).

Brent (1998) tells us that while Peirce was renowned in Europe, he was virtually unknown in the United States, which according to that biographer proves the lack of development of American philosophy at the time. Because he was not recognized by his American peers, and due to his prickly character academia rejected him. For 16 years, since 1867, the only recognition Peirce got in the United States resulted from his short stretch at Johns Hopkins.

And, finally, it is necessary to point out that Peirce's work was not markedly influenced by the philosophers that preceded him. Even though he knew Kant and Hegel, his work does not seem to take their work as a pivotal reference. However, according to peers, Peirce was a true scholar who was at least fifty years ahead of his time (EW, 1998).

Nowadays, Peirce is better known as a philosopher, although that portion of his work was only accomplished at the end of his career. In 1877 and 1878, he published six papers in Popular Science Monthly. The first two were The Fixation of Belief and How to make our ideas clear. In the latter he established his philosophical theory of pragmatism, by which he is now well-known (O'COONOR; ROBERTSON, 2005). Peirce has two basic themes: one, widely known, which he dubbed pragmatism or pragmaticism, and the other metaphysical or scholastic realism. In broad terms pragmatism is the theory of meaning, that is, a theory about how to make affirmations regarding the meaning of something (EW, 1998).

Founder of pragmatism, Peirce, later altered the name of his theory to pragmaticism, to distinguish his views from those of William James (EW, 1998). One of the reasons for distancing himself from James and the idealists was his distrust of subjectivism, he believed tainted all those philosophies (SW, 1958). Peirce argued that the truth of any statement must be assessed based on its practical consequences (which is the core of his pragmaticism) and their relationship with human interests. In other words, the concepts must be understood in terms of their practical implications (EW, 1998). The last work written by Peirce deals with the power of signs and religion. Peirce thought that the war between science and religion was logically unnecessary (SW, 1958).

Following in a very elementary manner the indicators of Peircean Pragmatism, we sought to translate and study his manuscripts concerning the study of arithmetic, written to be used in elementary schools, aiming to detect in them elements of his philosophical work. 


\section{Peirce's Primary Arithmetic: the manuscripts}

Charles Sanders Peirce (1839-1914) published a significant number of papers throughout life, however, the number of unpublished manuscripts left after his death was much greater. These included notes, reports, diaries, letters, lists, as well as complete papers and unfinished drafts. Edward C. Moore, in the foreword of Peirce (CE, 1982), speculates that the publication of Peirce's work could amount to 24 volumes of 500 pages each, whereas his unpublished work would amount to another 80 volumes. According to Brent (1998), one of Peirce's biographers, this amount of unpublished work, was created after he left Johns Hopkins University, from 1884 until his death in 1914.

In 1973, Max Fisch who, with the help of scholars such Carolyn Eisele, finally was able to organize the Manuscripts, so that they could be effectively used and cited by researchers, presented a proposal for a chronological edition of the Peircean Manuscripts which he called A Plan for a New Edition of the Writings of Charles Sanders Peirce. In 1975, the implementation of that plan became the responsibility of Indiana University. Max Fisch was appointed as chief editor of the project and the Peirce's Edition Project started in 1976 (HOUSER, 1998).

The Project aimed to create a definitive critical edition, organizing all of Peirce's work chronologically. Collections such as Collected Papers (CP) or The New Elements of Mathematics (NE), although not definitive, are at the genesis of the project that, now based in Indianapolis, aims to register the development and coherence of Peircean thought, providing a context that may bring new significance to all of his production.

In 1976, for the first time, Peirce's mathematical manuscripts, from the late XIX, were made public by Carolyn Eisele, in a compilation of four volumes that, still today, is a mandatory source of Peirce's mathematical production. The New Elements of Mathematics by Charles S. Peirce, edited by Eisele, contains studies on arithmetic, algebra, geometry, and some considerations on the philosophy of mathematics. Among such manuscripts are five short texts that would have been published as a teaching manual (or a series of teaching manuals) for American elementary schools, along with didacticpedagogical manuals for teachers. As all other manuscripts written by Peirce, the texts of Elementary Arithmetic suffered the effects of time, mainly due to the negligence of those individuals who, at the time, oversaw their conservation.

Eisele followed the order of the original texts of the Peirce Archive of the Harvard Houghton Library to classify the manuscripts (MS). Thus, Manuscript 189 (MS 189) - 
Lydia Peirce's Primary Arithmetic -, MS 181 and 182 - Primary Arithmetic (with suggestions to teachers) -, part of MS 179 - Peirce's Primary Arithmetic (upon the psychological method) -, MS 178 - C.S. Peirce's Vulgar Arithmetic: its chief features, and MS 168 (with examples from MS 167) - Practical Arithmetic - comprise a set of texts that we will call Elementary Arithmetic. According to Eisele, at that time, Peirce also intended to write an Advanced Arithmetic, in which he probably would develop topics regarding number theory, as he had already suggested in other Manuscripts (NE1, p. xxxv). Even though such superior or advanced arithmetic had been planned, it was never written or if it was, it has never been found. The texts that we are using as basis for the translation of the Manuscripts of Peirce's Elementary Arithmetic resulted from Eisele's systematization.

According to Eisele, Peirce himself stated in his letters that such manuscripts did not specifically deal with arithmetic, but with what might be called Augrim $^{12}$ which, for him would mean the art of using Arabic numerals. Peirce states that, unfortunately, such word had fallen into disuse and that trying to find a substitute proved to be rather difficult. The first word that comes to mind for substituting it is logistic, as the art of calculating in general. The expression vulgar arithmetic is an option that he found unsuitable and not inviting. Also, the expression practical arithmetic, according to Peirce, was faulty and no self-respecting writer would use it (even though he would contradict himself and use it frequently, mainly in manuscripts 167 and 168).

For Peirce, it would have been interesting to find a title that would be in line with the good old Elizabethan style (PEIRCE, 1976), however, it is impossible to understand, due to lack of detail, what he meant by that. In his further comments, Peirce stated that he had elaborated a draft for the entire work, and presented a summary of the themes of each volume he expected to write: (a) the aim of the first volume would be to make the subject interesting for the "little ones" and, according to Peirce, teachers' evaluations demonstrated the value of his method; (b) the second volume would deal with the concept of integers and decimals. Throughout his work, such numbers would be regarded as purely ordinal, without reference to intervals, however, he linked those to the question "how many are there?', thus treating these numbers through a counting standpoint. As it can be observed, at least at some point during the elaboration of the original texts, Peirce

\footnotetext{
12 This word is related to stones used for counting or to the term Arabic numerals. These are the few pieces of information that we were able to obtain about that. The only online dictionary entry that we would be able to find for Augrim is the one available at http://www.thinkenglish.me/definition/augrim.html
} 
intended to have all the manuscripts published in two volumes, when finished. Moreover, it is worth pointing out that, considering Peirce's remarks, however questionable, when dealing with the manuscripts ${ }^{13}$, his proposal had somehow been tested by teachers, who had approved of his method ${ }^{14}$.

Peirce himself and his biographers pointed out some of the references for the elaboration of the manuscripts. The influence of his father, Benjamin Peirce, is clear from the very beginning of Peirce's Primary Arithmetic: upon the psychological method, that complements MS 179, when the author states:

\begin{abstract}
My father, Professor Benjamin Peirce, a celebrated mathematician, was very particular to have me taught arithmetic, by the same method which he had very successfully learnt the art, only by improvements which his experience had suggested. Studies of modern psychology have enabled me still further to perfect this system; and after assuring myself by actual trial of this advantages, I here offer it in a practical form to the teachers of our people (NE1, p. 65).
\end{abstract}

Also, Thomas Fiske, may somehow have led Peirce to take charge of the task of producing the manuscripts for teaching elementary arithmetic. Twice, in 1894, Fiske, who had recently founded the American Mathematical Society, invited Peirce to publish in The Bulletin of the New York Mathematical Society. Peirce was a member of the Society and this might have influenced him in establishing his conceptions regarding mathematics education and teaching (NE1, 1976).

According to Eisele, in addition to the affiliation to the Society came the influence of Felix Klein regarding the directives for mathematics courses and teaching in the United States. Eisele also states that Peirce had significant knowledge of Klein's philosophy, and that there is evidence of Klein's influence throughout Peirce's manuscripts (PEIRCE, 1976). Peirce was also influenced by many volumes of the Bulletin, which dealt with discussions regarding what was understood as teaching mathematics at the time. According to Eisele, in a statement that can be considered questionable, at minimum, Peirce became a specialist in bringing to students and the general public an explanation

\footnotetext{
13 Peirce obtained an advance from his editor to write a series of teaching manuals. Profligate and disorganized as he was, Peirce stalled and postponed the delivery of the material until he found himself amid a judicial battle with the publishing company. In letters to friends, family, and employers, he would frequently lie about the progress of the work, to justify the delays, and not forfeit the possibility of new advances and/or need to return the amounts already received.

14 There is no reference to allow us to state Peirce had in fact any previous experience with teachers regarding these texts. On the contrary, Peirce's biography is filled with examples of his prickly personality and his personal and professional relationship difficulties, as well as marked by a significant distancing from the reality of primary and secondary, as well as higher education. Invested in benefiting from the publication of the manuscripts, it would not be implausible that the statements regarding the previous approval of his methods by teachers were another deceptive move for promoting the qualities that he, more than anyone else at the time, seemed to perceive in himself.
} 
of the mathematical methodology of his time, albeit he enjoyed little recognition for his work throughout his life.

Similarly to what occurred in Brazil, where the French influence in school text books was determinant for the standards of such materials, as well as the conception of school and teaching themselves; in American education at Peirce's time, the French model was almost hegemonic, with Legendre serving as a parameter for writers, as his books had been translated to English in 1819. Peirce's father also wrote teaching manuals for elementary school. His book on geometry, for instance, crossed American borders and was even analyzed by Lewis Carroll (2015) in his critique regarding the intention of the English of substituting Euclid's' book as a textbook for schools at the time for the book Geometry of Benjamin Peirce, that for Carroll, was one of the worthy rivals of Euclid in the mid nineteenth century.

In the beginning of the $\mathrm{XX}$ century, the need for reviewing the mathematics curriculum all worldwide became apparent. As a result, steps such as the creation of a committee chaired by Felix Klein were taken, during the International Congress of Mathematicians, in Rome, in 1908, ramping up the implementation of new ideas. According to Eisele, Peirce foresaw this revision in the elaboration of his own teaching manuals. The logical development of the subject, its symbolism, his resourcefulness, and his careful choice of nomenclature - reflecting his work as a linguist and lexicographer his profound appreciation of topological structure in the most basic levels of education, his fascination with non-Euclidean geometry, all of which according to Eisele, influenced his mathematical manuscripts.

It is impossible to present details of the manuscripts of Peirce's Primary Arithmetic in the present article. Thus, we recommend that those reading it in Portuguese read the articles of Garnica, Souza and Salandim (2018) and Souza, Garnica and Salandim (2018), as the complete Portuguese version has not yet been published. Likewise, to those reading in English, we recommend the "originals", published by Eisele in 1976. However, some considerations regarding each of such texts must be made.

\section{The Manuscripts: themes and approaches}

MS 189, entitled Lydia Peirce's Primary Arithmetic is composed by two versions of what would have been one single text: the first has two subheadings called Lessons, that are maintained in the second version, however that one is longer and more 
encompassing that the first. There are slight differences in intention between these two elaborations proposed by Peirce, and the most significant is the difference in the elaboration of the text.

In the present analysis of the manuscript it is important to reiterate that nothing regarding the concepts and algorithms that underpin the lessons, such as what quartersquares ${ }^{15}$ are, their origins, why multiplication can be done based on quarter-squares, how the multiplication by this method is done, etc., is discussed in the manuscript. We can affirm that this may mean the technique was well-known and widely used, or that in later revisions of the manuscript (which apparently were never completed by the author) this gap would have been detected and corrected. The only discussions occur through exemplification, however, it is our view that such exemplification is inadequate, as it is extremely cryptic and requires considerable mathematical knowledge (or pre-requisites).

Therefore, it can be suggested that Peirce had different audiences in mind when writing his elementary arithmetic. In some parts he addressed the children, in others he forgot them altogether and dove into calculations and sterile presentations, utterly inappropriate for children, assuming a much more knowledgeable sort of reader than those involved in the process of mathematical literacy, to whom the work was fundamentally intended. It can also be said that the strategies used by Peirce were blended with a complete unfamiliarity of the children's perspective, albeit he stated that his work was elaborated based on the study of state-of-the-art psychological and pedagogical theories, and their ways of learning, since the author's familiarity with real elementary schools was inexistent, as he had been himself homeschooled by his father.

The description of algorisms without any justification is a constant in all the manuscripts. However, as they were manuscripts, it cannot be attested whether these justifications would later be included in the final version of the text. Peirce's financial problems, which had accompanied him throughout adult life, combined with his academic arrogance and his very malleable approach to finances, however, leads us to consider that the elaboration of the manuscripts might have been hasty and irresponsible, merely to prove that the work was being conducted, so that the editors would pay him, solely based on the prospect of eventually obtaining the finished work. The work was neither

15 The multiplication process using quarter-squares is attributed to the Babylonians. The technique consists in multiplying $\mathrm{x}$ by $\mathrm{y}$ using quarter-squares from $\mathrm{x}+\mathrm{y}$ and $\mathrm{x}-\mathrm{y}$, applying equality $x \cdot y=\frac{(x+y)^{2}}{4}-\frac{(x-y)^{2}}{4}$. 
published, nor did the delivery of the final versions produce the expected results, as eventually the payments the publisher had been making to Peirce were interrupted.

Still, regarding multiplication, the author also deals with the so-called long process and its algorithm. There was, in fact, an attempt to justify the algorithm in a dialogue between two characters, called narrators, however this justification as well seems neither adequate, nor sufficient. For instance, how would an arithmetic which deals with multiplication be actually convincing without any previous mention of addition? Thus, the gap in the manuscripts is once again obvious, suggesting that Peirce apparently jotted down ideas as they occurred, so that he could later give them a better and more organized structure.

Victimized by countless comings and goings, poorly kept and shattered in many ways, which certainly resulted in the loss of several parts, the manuscripts are very difficult to analyze, thus one can only suggest possibilities, such as those we have presented thus far. Regarding this discussion, it is also relevant to question what would have motived Eisele to present the manuscripts in the order she proposed.

After multiplication, comes the topic regarding division. The motto of this topic is the numbered cards resource. The activities proposed usually suggest that the cards be distributed among the children that should form groups with them. Similarly, to other parts of manuscript number 189, language is not sophisticated: it is usual, ordinary. In addition to the cards, there is a series of problems that consist of dividing the hours of the day, which suggest the introduction of specific terminology (third, fifth, whole, quarter, division, quotient), and the respective notations in mathematical language, as well as the algorithm that, at the time, Peirce called short division. There is an interruption in this topic to deal with the topic of averages, which starts with a - very brief - discussion of the Julian and Gregorian calendar. It is only in few excerpts of the manuscript, that Peirce attempted to establish more fitting metaphors or explanations for children: "Both addition and multiplication make numbers larger /.../ if we speak of positive integers /.../", for instance.

The following and last topic of the manuscript, in the second version, is called "Problems with Cards", a tittle given by Eisele. Here, the cards, numbered 1 to 101 that Peirce will emphatically use as a pedagogical recourse throughout the manuscripts, are presented in a systematic manner for the first time. This was a series of sequentially numbered cards, which would be manipulated to exhaustion by both teachers and students as, according to Peirce, the learning resulting from the use of the cards demanded both 
accuracy and dexterity in handling. Thus, it was not just a matter of forming groups but forming them quickly, as well as answering questions about the groups formed. The cards must be laid out and collected, read, and again piled up and dealt according to the strict control of the person distributing them, always looking for patterns.

Manuscripts 181 and 182 are short texts entitled Primary Arithmetic (With Suggestions to Teachers). There is no indication of when one text finishes and the other begins. They are comprised of six lessons in total, of which the last is much longer than the previous. The emphasis is announced in the brief three-paragraph introduction: "The first thing to be done is to convey to the pupil as clear an idea of number as a child can have and to teach him to think of the digits, in simple, useful, and flexible diagrammatic images; and to associate with these the Arabic figures" (NE1, p. 43). Things should always be shown, displayed, never just assumed, and the cards, once again, whether numbered or not, play a fundamental role as a teaching object.

The reason for Peirce to interrupt a lesson and begin another cannot be understood. Most likely, the reasons for this interruption were varied and even mundane. As these are manuscripts, in the final version other exercises would likely have been included, complements or exclusions made, as there is no underlying logic to justify the link among the lessons. We must remember that the writing process of the manuscript had only one (unofficial) revisor, one of Peirce's colleagues, Edward Holden ${ }^{16}$ (1846-1914), an astronomer.

MS 179 -Peirce's Primary Arithmetic: upon the psychological method-begins in an (auto)biographical tone: the author talks about how his father, Benjamin, taught him. There is no clear link between the text of the manuscript and the title proposed by Eisele. What should have been, judging from the title, a discussion regarding the foundations of the psychological processes related to teaching and learning elementary arithmetic, wound up being a collection of short stories containing problem situations for teaching operations and concepts. Thus, the manuscript deals with the action of measuring without a reference pattern at hand or, in a more dramatic instance, collecting pennies during a stroll in the park to buy shoes for a poor girl.

\footnotetext{
${ }^{16}$ It is known that, at the beginning of the XX century, Peirce exchanged letters with Edward S. Holden. According to Peirce's biographers, Holden lent his support to the elaboration of the Arithmetic.
} 
Peirce's detailing of how to teach addition is nothing short of astounding. It is worth pointing out the explanation given for the addition of the pennies each child would give to purchase shoes for the underprivileged girl ${ }^{17}$ :

\begin{abstract}
Point with a pencil at each number, just as you are about to add it in; and that the pencil may not hide what comes next, begin at the bottom. Say 7, and point at the 4 , say 11 . Only do not say this loud, but keep your mouth shut, then move the pencil up, so as to point at the upper 4. Do not say 'and 4', even to yourself. But look at the 4 and say to yourself, 15; keeping your leaps firmly shut. If you stop to talk, you cannot add rapidly. Move your pencil up to the 3, and say to yourself, 18 . Move your pencil up to the upper 3 , and say to yourself, 21 . Move your pencil up to the 8 , and say to yourself, 29. Move your pencil up to the 5 , and say to yourself, 34 . Move your pencil up to the 6 , and say to yourself, 40. Move your pencil up to the 9 and say to yourself 49 . Move your pencil up to the 2 and say to yourself 51 . Move your pencil up to the 7 , and say to yourself, 58. Move your pencil up to the 11, and say to yourself 69. Draw a line under the column of figures and under it write 69. It is the sum total (NE1, p. 68).
\end{abstract}

The sum of tens will be better addressed by counting the syllables in a stanza of a religious hymn. The addition of tens is followed by subtraction. Adding $26+25+24+$ $25+27+22$ leads to the subtraction $365-31$, followed by the subtraction $62622250-$ 32067880. In other words, the level of difficulty presented to the children is totally chaotic. Once again, as seen in previous manuscripts, what should be done is explained in detail, however, the reason for doing it is not given.

Unlike previous operations, whose starting point was problem situations, without separation into specific topics, multiplication is presented with a specific subheading, at the end of the manuscript. In this topic, Peirce reinforces the need to emphasize agility, and mental counting. It is not enough to know the multiplication table and counting in sixes or sevens to know the product between 6 and 7: it is necessary to know, off hand, that 6 times 7 is 42 . The device that Peirce suggests to learn/teach mental multiplication is a cross, inspired by circular calendars of the Middle Ages, made of paper, and attached to the page through its center by a tread. The use of such cross introduces the concepts of multiple, diagonal, right, parity, and results such as multiples of even numbers are even. Once again, the numbered cards are used.

A footnote, specifically incorporated to the manuscript by Eisele, is significant for the analysis of the text. These are notes that Peirce makes to himself, as reminders:

In group-counting, the child has already practised addition and knows the tablet o perfection. Nothing remains but to accustom him to add in first one number and then another, together with the word. Introductory example. Poor Family without food. Each member contributed something. Put them down -

${ }^{17}$ This consists of adding $11+7+2+9+6+5+8+3+3+4+4+7=69$ 
Add them up. Find the sum total. Describe the process carefully. Family out walking finds little girl without shoes (NE1, p. 66).

There are also reminders about the terminology and concepts to be addressed within the text: "Terminology of addition: addition, add, cast up, sum. Sum total. To carry. Subtraction: subtract, deduct, rebate. Minuend. Subtrahend. Remainder, Remainer. To borrow" (NE1, p. 67). Some terminology, but not all of it, were addressed in this and other manuscripts. However, in none of the cases, can it be said that this approach is complete or definitive.

In manuscript 178, once again numbered cards play a fundamental role. They are distributed in decreasing order and used for playing games in which additions are proposed. For subtraction, regarded as "a trifle less facile than addition" (NE1, p. 86), a single two-line paragraph is reserved, stating that subtracting exercises will be useful to lessen the difficulty when conducting divisions through the long process. The discussion regarding multiplication follows this brief note regarding subtraction. This is intended to emphatically stimulate observation regarding the formation law, such as, for example, realize that no product in the multiplication table ends in 1, except once in each odd line, except for the fifth line.

These formation laws can be followed in a table to be created in the classroom or a device, a teaching aid, whose model Peirce later provides, so that it could be reproduced, with cardboard, by students or the teacher. Although the text does not provide any basis for the strategies used (a characteristic of the manuscripts, by the way), here the author indicates that an objection regarding the use of pedagogical devices / materials might be that "the teachers would not understand the mathematical principle on which it depends, and might therefore be exposed to embarrassing questions" (NE1, p. 89). However, nothing else is said about this matter.

When Peirce once more resorts to quarter-squares to operate multiplicatively, as he had done in MS 189, an explanation is given: that a booklet would be attached to Advanced Arithmetic and would serve both as a workbook and textbook. It appears that in the advanced book, which was either never written or never found, Peirce intended to lay the foundation of concepts and the operationalization from a mathematical standpoint, which therefore would make it more directly suitable for teachers or a more specialized public.

Moreover, the manuscript gives a lengthy, step by step, explanation (or rather presentation) of the multiplication algorithm through the long process, using as an 
example the product between 87183 x 366917 . Advanced Arithmetic to which Peirce also refers to as Higher Arithmetic, would deal with multiplication with the use of Crelle's Calculation Tables ${ }^{18}$. He states that the logarithms will be addressed later. Although, nothing regarding that statement could be found in the manuscript, the arithmetic treatment of the logarithm was registered. This would only be altered in the middle of the XX century, when the option becomes to work from a functional point of view, no longer as a result of progressions, but as part of the teaching of functions.

According to Peirce's manual, division is the natural start for advanced arithmetic. However, the treatment which he reserved for this topic in this manuscript is, at the very least, curious. He states:

With division higher arithmetic naturally begins, and for the most advanced pupil it will be proper here to insert a short course on that subject. But in the arrangement of the book it will be better to place all the theoretic matter together and to go on with Vulgar Arithmetic using such propositions of higher arithmetic as may be called for without attempting to prove or explain them (NE1, p. 95).

By doing that, he seems to try to refrain from justifying, in Elementary Arithmetic, any assertion, algorithm or technique beyond the description of their implementation and practical application. One example of why this approach is strange, at the very least, is in the following sentence: "It will have to be stated that the number of figures in the circulating decimal representing a fraction is equal to the totient ${ }^{19}$ of the denominator; that is, to the number of numbers less than that denominator and prime to it" (NE1, p. 95).

Judging by the deficiencies in teacher education in the United States of the time, one could assume that, with or without the support of an Advanced Arithmetic, through which such concepts would have been presented and discussed, such a proposition is too sophisticated from a mathematical standpoint, in any case. Nonetheless, from that statement stems a discussion regarding the study of remainders, in which the rules regarding remainders of division by $2,3,4,5,7,8,9,10,11,12,13,17,19$ and 23 are enunciated in paragraphs that can only be described as perversely torturous, in view of

\footnotetext{
${ }^{18}$ August Leopold Crelle (1780-1855) was a German engineer and mathematician, well-known in the history of mathematics for founding, in 1826, the Journal für die reine und angewandte Mathematik. His Rechentafeln (calculation tables) were published in 1820.

${ }^{19}$ Peirce's reference, here, Euler's Totient Function Such function, counts the positive integers up to a given integer $n$ that are relatively prime to $n$. In other words, it is the number of integers $k$ in the range $1 \leq k \leq n$ for which the greatest common divisor $\operatorname{gcd}(n, k)$ is equal to 1 .
} 
the training of elementary teachers in the United States, at the end of the XIX century (SOUZA; GARNICA; SALANDIM, 2018).

Once the rules regarding the remainders of division are presented, indicators for obtaining a periodical decimal number from an ordinary fraction are given. Beyond that, there is only a brief indication, to be subsequently developed, regarding the concept of involution ${ }^{20}$ and the observation that the books will ultimately deal with ordinal numbers, as, according to Peirce's brief observations (NE1, p. 102), "Cardinal number are nothing but ordinal numbers in a special application, to the order of multitudes". In this statement, he probably refers to studies regarding the cardinality of infinite sets, such as those conducted by Cantor, Frege and Dedekind, in which the Arithmetic of Transfinite Numbers is included. This adds yet another layer to the argument that the author had little familiarity with the education system and real classrooms, either in elementary schools, or teacher education of the time.

MS 168 is a typed version of MS 167, which was comprised of handwritten notes. Even though nothing is said about it, judging by the title, MS 167 contains examples (and exercises) which had not been included in MS 168 and that Eisele combined to form a single text, comprised of four chapters in her edition of The New Elements of Mathematics.

In the fairly brief first chapter, Arithmetic (the knowledge of numbers) and Practical Arithmetic (the knowledge of how to use numbers) are defined (NE1, p. 107). Here the term "practical arithmetic" is used, even though Peirce himself stated in another manuscript that he considered it inadequate. A significant portion of the chapters deal with the elaboration of concepts, terms, and expressions, as if in a sequence of entries, which the author enunciates from the roots of such words in ancient languages.

This introduction which occupies the whole first chapter, effectively reinforces what Peirce had already emphatically pointed out in other manuscripts, for the practice of the lessons proposed: "Two qualities are to be aimed at, - accuracy first, and then dispatch" (NE1, p. 107). Accuracy is understood as agility in calculation and counting, to which the set of manuscripts dedicates a great number of repetition activities, with mnemonic cues and awards for the correct answers given more quickly by students.

\footnotetext{
${ }^{20}$ Involution the antonym of evolution. In mathematics this word is used regarding an inversion process. In this case, given a periodical decimal number, get the fraction that generates such number, as the treatment proposed by Peirce, up to this point, consisted in finding the decimal number when given the fraction that represents it.
} 
Numeration - "a branch of Arithmetic which teaches the art of forming numerals, or names of numbers" (NE1, p. 108) - is the theme of the second chapter. Here, it seems the emphasis is to register a glossary that up to the end of the manuscript will contain entries such as Arithmetic, Algorithm, Numeral, Decimal, Unit, Digit and Arabic Notation. The focus is on counting, either sequentially, or regarding the knowledge of Units of Measure (measures of length, mass, area, volume, and money).

These manuscripts are the most intellectual of the whole set. Even though, Peirce's knowledge regarding other cultures and science, in general, is shown in other moments in the manuscripts, in this one it is omnipresent. One exercise about counting beans closes this chapter. However, problems and examples in subsequent chapters, will bring planetary movement, demographic and occupational data, as well as the height of some mountains around the globe. In this manuscript, there is a note by Peirce stating that the information regarding data on the geography of the Earth were obtained in the Annnuaire des Longitudes of 1888, a dissemination leaflet published by the French Bureau des Longitudes, created in 1795 (the third year of the revolutionary calendar). To this day, the Annnuaire publishes and updates data on geophysical and astronomical measures, similarly to the Coast and Geodetic Survey, its American counterpart.

\section{A possible conclusion}

With the translation of the manuscript to Portuguese and the studies of that translation (always compared with the originals in English), combined with reviews regarding the social, cultural, political and educational scenario at the end of the $1800 \mathrm{~s}$, in addition to an exhaustive survey of Peirce's biography, some more encompassing understandings about his Primary Arithmetic can be achieved.

It is important to point out that the hermeneutics of unfinished manuscripts, which are most likely incomplete, constitutes an extremely arduous task, due to the scattering of the originals and carelessness with which they have been treated throughout history. For instance, there is no accurate information regarding what led Eisele to choose to present the manuscripts in that specific order, combining some of them and separating others. However, it must be pointed out that favoring a specific sequence, cutting texts and combining them in a specific way, elaborating a less truncated text, aiming to achieve some cohesion, would imply even more subjective decisions, which Eisele prudently avoided, in our opinion. There are not even definite or precise indications regarding what 
Peirce thought would be minimally adequate for the final composition. The result is that one must deal with what is at hand: a set of notes marked by discontinuity, repetition of themes and lack of an unequivocal sequence.

Nonetheless, Eisele's appreciation of these manuscripts seems to be overly effusive, as she barely points out the (natural) limitations of an interpretation that is based solely on unfinished work. She points out, for instance, Peirce's familiarity with Klein's proposals in relation to initiatives for the reform of the mathematics curriculum, which became more explicit at the end of the nineteenth century.

According to Eisele, his work was modern and his clear and rigorous explanations, contained advanced guidelines on teaching methodology. Perhaps this emphasis may characterize Peirce's mathematical work that is quite extensive, as we know, and has been intensively studied and compiled by Eisele in the four great volumes of The New

\section{Elements of Mathematics of C.S. Peirce.}

However, regarding the Elementary Arithmetic, although some specific proposals for teaching mathematics are quite clear, the emphasis on repetition, the lack of more detailed justifications explained in way which is more suitable for teachers who have received a somewhat deficient education are apparent throughout; the variation in tone while introducing content and Peirce's indecision regarding who the ultimate targetpublic of the manuscripts is, also distinctively mark this set of texts.

These characteristics might be explained by Peirce's lack of experience regarding the reality of the American educational system, which he did not attend as student himself, as during his childhood he was home schooled by his father, and by his prickly personality, especially when living at his own expense, after losing the support of his father, who had been his entryway to several very privileged social and academic circles at the time, when he faced many financial problems, aggravated by his failing health, arrogance and his inability to function in social and professional environments ${ }^{21}$.

His deal with the editors for the publication of the manuscripts would help Peirce remedy, even if partially, his predicament with numerous creditors. However, his disorganization prevented him from completing them. What stands out from the remainder of these texts, a group of general, disconnected notes, which, at least for some

\footnotetext{
${ }^{21}$ Eisele reiterates the fact that Peirce and his extensive production did not receive recognition during his lifetime, however she does not consider these biographical data as playing any role in the resistance of academia.
} 
time, may have served to appease the demands of editors that ended up terminating their contract with the author.

The texts, in which the author sometimes addresses children directly, and other times deals with content and teaching proposals aimed at teachers, may suggest that there would be at least two main approaches to be focused on: one regarding the teaching material itself, to be used in the classroom, and another regarding the materials that would have been used as a teachers' manual, for pedagogical support, in a more colloquial language.

According to Eisele, Peirce himself suggested a possibility that should also be considered; that there would be at least two other approaches for Elementary Arithmetic: one regarding Elementary Arithmetic strictly speaking (the meaning of elementary as initial, introductory, basic), and another related to the foundation of concepts involved in this arithmetic (probably what Peirce referred to as Advanced or Higher Arithmetic).

On the other hand, some innovations are clear in the use of creative teaching strategies. Peirce's intention to use the language of children by using rhyme, rhythm and children's stories is particularly notable in some points of the manuscripts. Such stories are based on classic elements such as family, the patient, fair and wise grandmother, teachers and students, a cabin in the woods, and some peculiar situations, such as one that proposes hunting for hidden treasures or searches in the woods.

Examples and exercises include elements of American history, and include information related to general literate culture, in an effort to expose the children to discussions regarding technological novelties and aspects of geography, traditions of the US and other countries, as well as general history. From these many elements, the use of pedagogical materials such as abacus, games, tables, datasheets, and cards. Surely, such resources would need to be revisited, emphasized, and better organized by the author and distributed through several volumes. However, what was left of the manuscripts is more than enough to attest Peirce's intentions while elaborating the text - as a teaching manual to be used by children in the classroom - shall we say, appropriate to childhood education and present it as a potential educational innovation.

According to the author himself, it was written to outshine the teaching manuals used at the time ${ }^{22}$, however, innovations that, according to Eisele, would be present in

\footnotetext{
22 "Sheldon's Elementary Arithmetic begins with it. He sticks down $1+1=2$, right at the very first! Before introducing the number 4! That is madness! Wentworth Primary Arithmetic introduces the thing but not the name before use of all the numbers. He puts off the use of the name very injudiciously. Greanleaf's First
} 
them, cannot be clearly detected. Moreover, it is not possible to clearly indicate any approach deriving from a more consistent philosophical foundation. The Manuscripts of Peirce's Primary Arithmetic are the product of the circumstances that created them and prevented their completion. They seem to have been guided more from what Peirce believed to be his common sense and his knowledge of the scientific production at the time, without a more tangible concern for teachers and students who would ultimately use the texts.

\section{References}

BRENT, J. C. S. Peirce: A life. 2. ed. Bloomington: Indiana University Press, 1998.

CARROLL, L. Euclides e Seus Rivais Modernos. (Carroll's Euclid and His Modern Rivals translation to Portuguese). 1. ed., São Paulo: Editora da Física, 2015.

CASSIDY, M. F. Toward Integration: Education, Instructional Technology, and Semiotics. Educational Communication and Technology, [S.I.], v30, n. 2, p. 75-89, 1982.

(CE) PEIRCE, C. S. Writings of Charles S. Peirce: A Chronological Edition. Bloomington: Indiana University Press, 1982.

COOPER, T. L. The concepts of knowledge of Peirce and Dewey - The relation to education. Stanford University, CA (unpublished paper), 1967.

(CP) PEIRCE, C. S. Collected Papers of Charles Sanders Peirce. In: HARTSHORNE, C.; WEISS, P.; BURKS, A. W. (ed.). Cambridge: Harvard University Press, 1931-1958. v. 1- 6, p. 1931-1935; v. 7 - 8, p. 1958

EISELE, C. Charles S. Peirce Nineteenth Century Man of Science. Scripta Mathematica 24, [S.I.], p. 305-324, 1959.

(EW) PEIRCE, C. S. Charles S. Peirce: the essential writings. Amherst: Prometheus Books, 1998.

GARNICA, A.V. M. Peirce's Mathematical Writings: an essay on Primary Arithmetic Books as it relates to Mathematics Education. Revista Brasileira de História da Matemática, Rio Claro, v. 1, n. 2 . p. $37-57,2001$.

GARNICA, A.V.M., SOUZA, L.J. de. A Aritmética Elementar de Peirce - Tradução e Comentários. (unpublished book - Peirce's Primary Arithmetic Manuscripts translated to Portuguese)

GARNICA, A. V. M.; SOUZA, L.J de; MARTINS-SALANDIM, M. E. Dos Manuscritos da Aritmética Elementar de Charles S. Peirce: uma breve apresentação e algumas considerações sobre sua tradução. Bolema, Rio Claro, v. 32, p. 322-353, 2018.

Lessons does about the same. Rickoff First Lessons in Arithmetic does the same. The Franklin the same. Ray's New Primary avoids this great mistake. Robinson's New Primary partly avoids it. Robinson's Progressive Primary wholly avoids it" (NE1, p. 67). 
HOUSER, N. The Fortunes and Misfortunes of the Peirce Papers. Available in: http://www.cspeirce.com/menu/library/aboutcsp/houser/fortunes.htm. Access in: May 31st, 2016. Arisbe website, 1998.

KLINE, M. Logic Versus Pedagogy. American Mathematical Monthly, [S.I.], v. 77, n. 3, p. 264-282, 1970.

McCARTHY, J.M. Was Peirce an 'Educational' Philosopher? Paper presented at the annual meeting of the New England Educational Research Organization, 1971.

(NE) PEIRCE, C. S. The New Elements of Mathematics of Charles S. Peirce. EISELE, C (ed.). 1. ed. The Hague: Mouton Publishers, 4. v, 1976.

O'CONNOR, J. J.; ROBERTSON, E. F. Charles Sanders Peirce. 2005. Available in: http://www-history.mcs.st-andrews.ac.uk/Biographies/Peirce_Charles.html. Access in: June 2nd, 2016.

RANSDELL, J. Peirce est-il un phénoménologique? Ètudes Phénomenologiques, [S.I.], v. 9-10, p. 51-75, 1989.

SOUZA, L.J de; GARNICA, A. V. M.; MARTINS-SALANDIM, M. E. Dos manuscritos da Aritmética Elementar de Charles Sanders Peirce: um cenário sócio-histórico. Perspectivas da Educação Matemática, Campo Grande, v. 11, p. 115-141, 2018.

STROM, D, KEMENY, V., LEHRER, R., FORMAN, E. Tracing the Semiotics of a Mathematical Argument. University of Wisconsin-Madison/University of Pittsburgh. (Draft), 1999.

(SW) PEIRCE, C. S. Charles S. Peirce Selected Writings: Values in a Universe of Chance. 1. ed. The Hague: Mouton Publishers, 1958.

Received in: July 23, 2020.

Accepted on: September 15, 2020. 